\title{
Regional integration and south-south cooperation in health in Latin America and the Caribbean
}

\author{
Alejandra Carrillo Roa ${ }^{1}$ and José Paranaguá de Santana²
}

Suggested citation

Carrillo Roa A, Santana JP. Regional integration and south-south cooperation in health in Latin America and the Caribbean. Rev Panam Salud Publica. 2012;32(5):368-75.

ABSTRACT This paper analyzes whether south-south cooperation is legitimately a recent practice or merely an improved version of previous regional integration processes in Latin America and the Caribbean. The authors reviewed and systematized the historic development of subregional integration processes in Latin America and the Caribbean and focused on health cooperation in the following contexts: the Central American Integration System, the Andean Community of Nations, the Caribbean Community, the Amazon Cooperation Treaty Organization, the Southern Common Market, and the Union of South American Nations. The study concludes that the conceptual and methodologic foundations of south-south cooperation in health were born from and nurtured by the processes of regional integration in Latin America and the Caribbean. This paper posits that regional political and economic integration initiatives bring potential benefits to the health sector and act as an important mechanism to develop south-south cooperation in this domain. The study recommends furthering this type of research to provide information that will allow national and multilateral agencies, or other stakeholders, to formulate and implement better policies for international health cooperation that target reducing inequities and promoting health and wellbeing for all people.

Key words International cooperation; technical cooperation; horizontal cooperation; Latin America.

South-south cooperation (SSC) has acquired a progressively relevant position on the agendas of Latin America and the Caribbean (LAC) subregional blocs as a strategy for development. A strong argument to establish health as a priority in cooperation emerges from the commitment made by member countries of the

\footnotetext{
${ }^{1}$ Center for Bioethics and Health Diplomacy Studies, Campus Universitário Darcy Ribeiro, Brasilia, Brazil. Send correspondence to: Alejandra Carrillo Roa, acarrilloroa@gmail.com

${ }^{2}$ Organização Pan-Americana da Saúde, Representação no Brasil, Brasília, Brazil.
}

United Nations (UN) to the millennium development goals, of which three are directly linked to health and the other five are correlated.

At the same time, failure to reduce economic and social inequalities between developed countries, mostly located in the north, and developing nations, in the south, discredits the effectiveness of traditional cooperation models, identified as north-south cooperation (NSC). The fact that developing countries continue to be called such shows a lack of meaningful development in spite of decades of international aid and technical cooperation (1).

SSC appears as an innovation or transformation of international cooperation (2) in the midst of a process of changes occurring in international relations where global southern countries plan to build cooperation projects, including with support of the wealthiest countries and mediation of the UN, but truly fitting in the designs of their own development (3). Such innovations in health care are being heralded as a paradigm of cooperation. For instance, the Bra- 
zilian structuring approach to health cooperation states that, compared with previous paradigms, this new paradigm innovates in two respects: it includes the training of human resources, organizational strengthening, and institutional development and it breaks with the traditional passive transfer of knowledge and technologies (4).

Undoubtedly, SSC brings fresh impetus to international cooperation. However, it is worth asking whether it is legitimately a recent practice and whether the new paradigms are truly innovative or merely enhanced editions of previous regional integration processes in LAC.

This paper aims to answer that question by reviewing and systematizing the historic development of subregional integration processes in LAC and focusing on health cooperation in the following contexts: the Central American Integration System, the Andean Community of Nations (CAN), the Caribbean Community (CARICOM), the Amazon Cooperation Treaty Organization (ACTO), the Southern Common Market (MERCOSUR), and the Union of South American Nations (UNASUR). Although NSC is recognizably an important reference in this debate, comparing NSC with SSC is beyond the scope of this study.

A brief historic review of SSC is introduced, given its importance in constructing the proposed narrative. Then the historic development of health cooperation within LAC regional integration processes is presented. Finally, certain elements of such processes that eventually became core characteristics of SSC are highlighted.

\section{SOUTH-SOUTH COOPERATION}

The meaning of SSC dates back to the emergence of southern consciousness (2). ${ }^{3}$ The Bandung Conference in 1955, the Nonaligned Movement in 1961, and the Group of 77 in 1964 were the first political dialogues between southern countries to promote shared interests and to strengthen their negotiating capacity in the unequal international system established after World War II.

The Buenos Aires Plan of Action, approved by delegates from 138 countries

\footnotetext{
${ }^{3}$ Southern consciousness can be defined as having occurred when developing countries, identified as the south, recognized their common identities and challenges and realized the need to join forces against international system asymmetries.
}

during the UN Conference of September 1978, introduced the term "technical cooperation between developing countries" and recognized that, in addition to being recipients, developing countries were becoming cooperation donors (5). Although expectations were high, hopes were dashed after the meeting in Buenos Aires. The oil crises of the 1970s substantially increased international interest rates and adversely affected developing countries already floundering in foreign debt and high inflation. The effects of the debt crisis of the 1980s and estrangement of the nonaligned integration movement induced developing countries to seek individual negotiations with wealthy countries. In the 1980s and early 1990s, structural adjustment programs based on neoliberal principles occupied the center of economic and political formulations as well as international cooperation (4). The excessive conditions required by donors made it difficult for recipient countries to appropriate aid.

Numerous studies have shown that aid priorities were correlated not to the needs of recipient countries but to the needs of donors (6-12). Many traditional practices of cooperation sought to export local products, services, and capital; to secure access to strategic materials; and to obtain political privilege $(13,14)$. Furthermore, a lot of foreign aid has been characterized by volatility, unequal and inequitable patterns of distribution, contingency on all donor interests, and lack of responsibility or accountability (15).

Consequently, the perceived failure of structural adjustment programs embedded in a number of traditional Official Development Assistance programs became widespread during the late 1980s and the 1990s, which led the UN to develop an alternative for promoting development that took social, environmental, and human rights concerns into account. Thus, the processes of regional integration regained momentum and provided a basis for SSC, which has been propelled both by the impulse of emerging countries and by the fatigue of traditional donors (15).

As the leading actors in SSC, emerging countries rely on traditional diplomatic schemes but conduct them in ways that contrast with NSC, as they focus on the exchange of experiences, knowledge, and techniques adjusted to the realities of other southern countries $(16,17)$. "In fact, one major advantage of southern donor countries in technical cooperation is that they are able to draw on their own experiences that more closely resemble program country contexts than those of northern donors" (18). They strive for recognition in the international arena with a renewed discourse of opposition to the prevailing world order $(19,20)$. Despite difficulties in defining the SSC, there is a consensus on its governing principles: solidarity and equal relationships, reciprocal benefits, respect for national sovereignty, shared responsibility, noninterference, nonintervention, selfdetermination, and independence. SSC admits that it complements rather than substitutes for NSC (20), although its origins are based on opposition to traditional practices of cooperation $(3,4)$.

Some authors list the following advantages of SSC: greater flexibility for transferring good practices; better adaptation of cooperation initiatives to recipient needs; horizontal cooperation; less or no conditionality linked to assistance; reduced economic cost of initiatives; swift and direct impact on the beneficiary population; preservation of local cultural diversity and identity; and increased use of local resources, which generates an increased sense of ownership $(2,6,15)$. These issues are controversial, as the same authors and others also list SSC limitations that partially coincide with the ills of NSC: fragmented assistance and coordination problems among donors, lack of accessible and understandable information, financing difficulties, not necessarily aligned with development strategies of the recipient, and little impact assessment culture (2, $6,15,18)$.

Even if one considers horizontal relations as a distinctive aspect of SSC, it would be naïve to ignore specific foreign policy interests, even among nations of the south $(3,21)$. In short, SSC is a concept with ideologic, political, and technical hues that is innovating international cooperation for development but whose operation has not fully pulled away from the paradigm of traditional NSC.

\section{REGIONAL INTEGRATION AND SOUTH-SOUTH COOPERATION IN HEALTH}

In the past four decades, LAC countries have identified challenging health problems they have in common and have ad- 
FIGURE 1. Timeline of regional integration and south-south cooperation in health in Latin America and the Caribbean

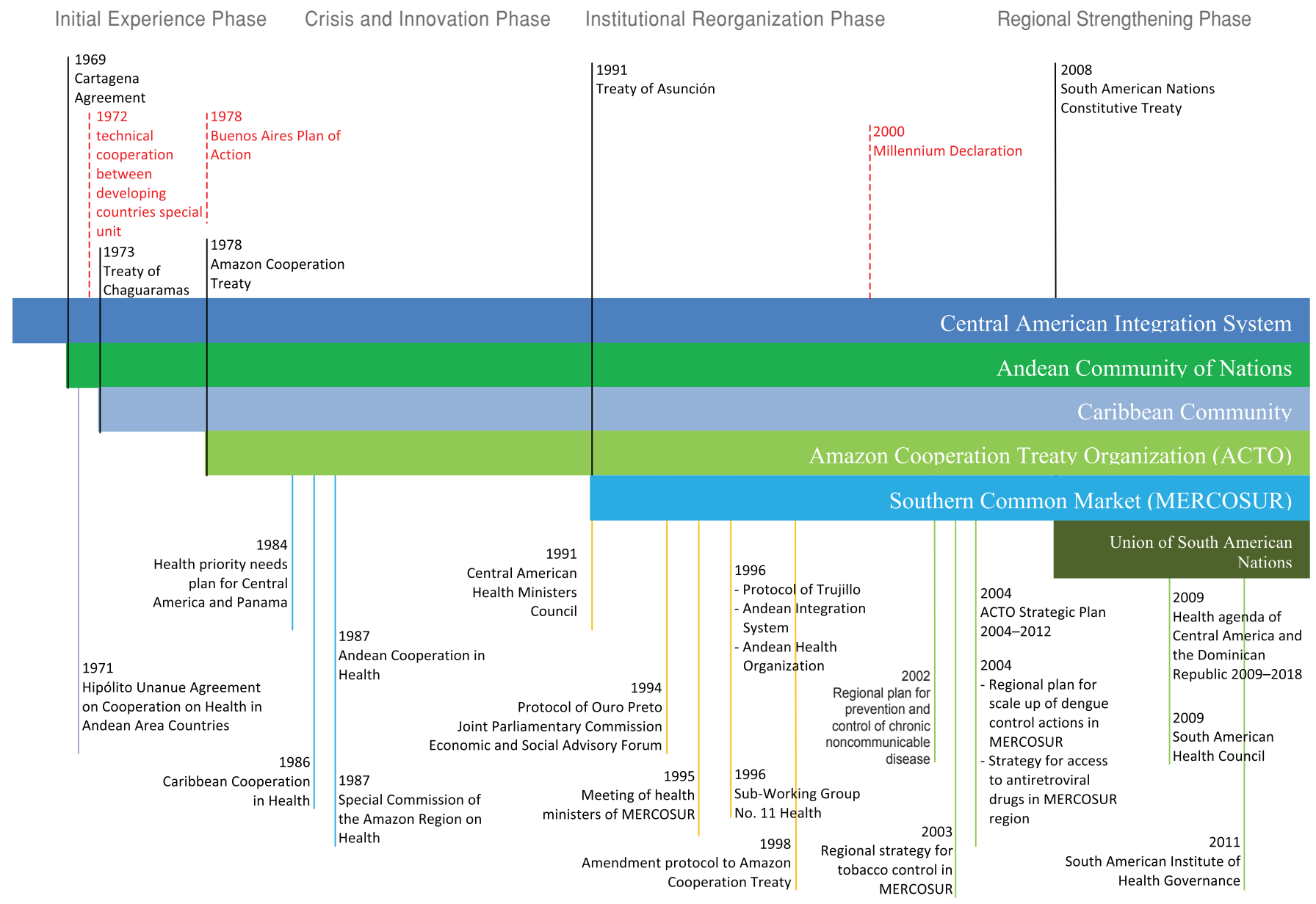

opted cooperation as a means to address them more effectively. Taking into consideration the peculiarities of each subregion while avoiding the reductionism of interpretation, this exploratory study briefly presents the history of health cooperation as it developed at the core of subregional integration processes.

Four historic phases, named according to the general characteristics of health integration processes experienced in different LAC subregions, are proposed: initial experiences (1970-1980), crisis and innovation (1980-1990), institutional reorganization (1990-2000), and regional strengthening (2000-2010). Figure 1 and Table 1 summarize these phases, as detailed below.

\section{Initial experiences}

The first subregional blocs in Latin America to implement initiatives in the health field were CAN, CARICOM, and ACTO. ${ }^{4}$

The Andean Pact, now CAN, emerged as subregional protectionism in response to the unsuccessful attempt of the Latin American Free Trade Association to form a free trade area in Latin America (22). Although the bloc's primary emphasis was on economic and trade integration, the agreement included social integration and cooperation (23). This agreement resulted in the Hipólito Unanue Agreement on Health Cooperation between Andean Countries, signed in 1971 (24). It is the first formal initiative of subregional health cooperation in Latin America, ahead of the 1972 special unit for technical cooperation between devel-

\footnotetext{
${ }^{4}$ The Organization of Central American States, now Central American Integration System, although founded in 1951 through the Charter of San Salvador, did not sign a specific agreement in the field of health until the 1980 s.
}

oping countries and approval of the 1978 Buenos Aires Plan of Action.

The Caribbean Community was established in 1973 by the Treaty of Chaguaramas. This region has a long history of health cooperation. Even before CARICOM, the region had established several cooperative health activities; among them, the Medical School of the University of the West Indies started in 1948 under the auspices of the University of London, the Caribbean Food and Nutrition Institute in 1967, the Medical Research Council of the Caribbean Community in 1972, and the Caribbean Epidemiology Center in 1974. Creation of the Medical School of the University of the West Indies signaled that Antillean governments recognized how locally trained physicians were best fit to address regional health issues (25).

The Amazon Cooperation Treaty (ACT), signed in July 1978, included pro- 
TABLE 1. Summary of south-south cooperation initiatives in health in subregional blocs in Latin America and the Caribbean

\begin{tabular}{|c|c|c|c|c|c|}
\hline $\begin{array}{l}\text { Subregional bloc: } \\
\text { country, year of } \\
\text { establishment }\end{array}$ & Member countries & $\begin{array}{l}\text { Integrative initiatives in } \\
\text { health: country, year of } \\
\text { establishment }\end{array}$ & $\begin{array}{l}\text { Goals of initiatives in } \\
\text { health }\end{array}$ & $\begin{array}{l}\text { Health political body: } \\
\text { country, year of } \\
\text { establishment }\end{array}$ & $\begin{array}{l}\text { Relevant health documents: } \\
\text { country, year of adoption }\end{array}$ \\
\hline $\begin{array}{l}\text { Central American } \\
\text { Integration System: El } \\
\text { Salvador, } 1951\end{array}$ & $\begin{array}{l}\text { Belize, Costa Rica, El } \\
\text { Salvador, Guatemala, } \\
\text { Honduras, Nicaragua, } \\
\text { and Panama }\end{array}$ & $\begin{array}{l}\text { Central American Health } \\
\text { Initiative: Costa Rica, } \\
1984 \\
\text { Plan of Immediate } \\
\text { Actions in Health } \\
\text { in Central America: } \\
\text { Honduras, } 1995\end{array}$ & $\begin{array}{l}\text { Use health as a bridge } \\
\text { to peace by identifying } \\
\text { common problems and } \\
\text { jointly solving them. }\end{array}$ & $\begin{array}{l}\text { Central American Health } \\
\text { Ministers' Council: } \\
\text { Honduras, } 1991\end{array}$ & $\begin{array}{l}\text { Declaration of Montelimar: } \\
\text { Nicaragua, } 1990 \\
\text { Declaration of Belize: } \\
\text { Belize, } 1990 \\
\text { Declaration of Tegucigalpa: } \\
\text { Honduras, } 1991 \\
\text { Health Agenda of Central } \\
\text { America and the Dominican } \\
\text { Republic } 2009-2018 \text { : } \\
\text { Honduras, } 2009\end{array}$ \\
\hline $\begin{array}{l}\text { Andean Community of } \\
\text { Nations: Colombia, } 1969\end{array}$ & $\begin{array}{l}\text { Bolivia, Colombia, } \\
\text { Ecuador, and Peru }\end{array}$ & $\begin{array}{l}\text { Hipólito Unanue } \\
\text { Agreement on } \\
\text { Cooperation on Health } \\
\text { in the Andean Area } \\
\text { Countries: Peru, } 1971 \\
\text { Andean Cooperation in } \\
\text { Health: United States of } \\
\text { America, } 1987\end{array}$ & $\begin{array}{l}\text { Strengthen national and } \\
\text { subregional capacity in } \\
\text { health through better use } \\
\text { of technical resources } \\
\text { and autochthonous } \\
\text { institutions. }\end{array}$ & $\begin{array}{l}\text { Health Ministers' } \\
\text { Council: country not } \\
\text { available, } 1972\end{array}$ & $\begin{array}{l}\text { Cartagena de Indias } \\
\text { Manifest: Colombia, } 1989 \\
\text { Protocol of Trujillo: Peru, } \\
1996 \\
\text { Integrated Social } \\
\text { Development Plan: United } \\
\text { States of America, } 2004\end{array}$ \\
\hline $\begin{array}{l}\text { Caribbean Community: } \\
\text { Trinidad and Tobago, } \\
1973\end{array}$ & $\begin{array}{l}\text { Antigua and Barbuda, } \\
\text { Bahamas, Barbados, } \\
\text { Belize, Dominica, } \\
\text { Grenada, Guyana, Haiti, } \\
\text { Jamaica, Montserrat, } \\
\text { Saint Lucia, Saint Kitts } \\
\text { and Nevis, Saint Vincent } \\
\text { and the Grenadines, } \\
\text { Surinam, and Trinidad } \\
\text { and Tobago }\end{array}$ & $\begin{array}{l}\text { Caribbean Cooperation } \\
\text { in Health: country not } \\
\text { available, } 1984 \\
\text { Pan Caribbean } \\
\text { Partnership } \\
\text { Against Human } \\
\text { Immunodeficiency } \\
\text { Virus-Acquired Immune } \\
\text { Deficiency Syndrome: } \\
\text { Barbados, } 2001 \\
\text { Regional Initiative } \\
\text { for Human } \\
\text { Immunodeficiency } \\
\text { Virus- and Syphilis-Free } \\
\text { Generations: United } \\
\text { States of America, } 2009\end{array}$ & $\begin{array}{l}\text { Share knowledge and } \\
\text { experiences with other } \\
\text { Caribbean countries, } \\
\text { mainly in treatment of } \\
\text { similar problems. }\end{array}$ & $\begin{array}{l}\text { Council for Human and } \\
\text { Social Development: } \\
\text { Guyana, } 2001\end{array}$ & $\begin{array}{l}\text { Declaration on Health for } \\
\text { the Caribbean Community: } \\
\text { Saint Lucia, } 1982 \\
\text { Revised Chaguaramas } \\
\text { Treaty: Trinidad and } \\
\text { Tobago, } 2001 \\
\text { Nassau Declaration: } \\
\text { Bahamas, } 2001 \\
\text { Port of Spain Declaration: } \\
\text { Trinidad and Tobago, } 2007\end{array}$ \\
\hline $\begin{array}{l}\text { Amazon Cooperation } \\
\text { Treaty Organization } \\
\text { (ACTO): Brazil, } 1978\end{array}$ & $\begin{array}{l}\text { Bolivia, Brazil, Colombia, } \\
\text { Ecuador, Guyana, Peru, } \\
\text { Surinam, and Venezuela }\end{array}$ & $\begin{array}{l}\text { Pan Amazonian Network } \\
\text { of Science, Technology } \\
\text { and Innovation in Health: } \\
\text { Brazil, } 2007\end{array}$ & $\begin{array}{l}\text { Support strengthening } \\
\text { of national and regional } \\
\text { capacity for studies, } \\
\text { technology, and } \\
\text { innovation in health } \\
\text { to improve health } \\
\text { conditions of the } \\
\text { Amazonian population. }\end{array}$ & $\begin{array}{l}\text { Special Commission of } \\
\text { the Amazon Region on } \\
\text { Health: Brazil, } 1988\end{array}$ & $\begin{array}{l}\text { Santiago de Cali } \\
\text { Declaration: Colombia, } \\
1983 \\
\text { Manaus Declaration: Brazil, } \\
2004 \\
\text { ACTO Strategic Plan: } \\
\text { country not available, } 2004\end{array}$ \\
\hline $\begin{array}{l}\text { Southern Common } \\
\text { Market (MERCOSUR): } \\
\text { Paraguay, } 1991\end{array}$ & $\begin{array}{l}\text { Argentina, Brazil, } \\
\text { Paraguay, and Uruguay }\end{array}$ & $\begin{array}{l}\text { Health Sub-Working } \\
\text { Group 11: Brazil, } 1996\end{array}$ & $\begin{array}{l}\text { Harmonize legislation } \\
\text { in member states with } \\
\text { regard to health goods, } \\
\text { services, and raw } \\
\text { materials and products; } \\
\text { aim to promote and } \\
\text { protect health and life of } \\
\text { population and eliminate } \\
\text { obstacles to regional } \\
\text { trade. }\end{array}$ & $\begin{array}{l}\text { Meeting of health } \\
\text { ministers of } \\
\text { MERCOSUR: country } \\
\text { not available, } 1995\end{array}$ & $\begin{array}{l}\text { Protocol of Ouro Preto: } \\
\text { Brazil, } 1994 \\
\text { Minimum matrix of } \\
\text { professional exercise: } \\
\text { Brazil, } 2004 \\
\text { Harmonization of goals } \\
\text { for tobacco control in } \\
\text { MERCOSUR: Brazil, } 2006\end{array}$ \\
\hline $\begin{array}{l}\text { Union of South American } \\
\text { Nations (UNASUR): } \\
\text { Brazil, } 2008\end{array}$ & $\begin{array}{l}\text { Argentina, Bolivia, } \\
\text { Brazil, Chile, Colombia, } \\
\text { Ecuador, Guyana, } \\
\text { Paraguay, Peru, } \\
\text { Surinam, Uruguay, and } \\
\text { Venezuela }\end{array}$ & $\begin{array}{l}\text { UNASUR Health: Brazil, } \\
2008 \\
\text { South American Institute } \\
\text { of Health Governance: } \\
\text { Brazil, } 2011\end{array}$ & $\begin{array}{l}\text { Improve quality of } \\
\text { South America's } \\
\text { health governance by } \\
\text { training leaders, using } \\
\text { knowledge management, } \\
\text { and providing technical } \\
\text { support to health care } \\
\text { systems. }\end{array}$ & $\begin{array}{l}\text { Health Ministers' } \\
\text { Council: Brazil, } 2009\end{array}$ & $\begin{array}{l}\text { Five-Year Plan 2010- } \\
\text { 2015-South American } \\
\text { Health: Ecuador, } 2010\end{array}$ \\
\hline
\end{tabular}

posals for promoting and coordinating international actions not only in health care but also with regard to scientific and technological research in this field (26).

\section{Crisis and innovation}

The regional and world economic crisis of 1980 weakened the coopera- tion processes among Latin American countries, which were required to follow the guidelines and priorities set by international financial institutions. This 
situation caused breaks in cooperation processes begun earlier, undermining the incipient institutional structures of country blocs.

Worsening poverty, inequality, and social exclusion that resulted from the crisis spurred new forms of interaction that corresponded to the resource shortages in the region, expanding international cooperation into a crisis reaction strategy. Competition for these scarce resources intensified the search for international assistance and fed the trend to modernize cooperation practices.

The experience of the Central American Integration System clearly demonstrates this trend. The precarious economic, political, and social conditions that surrounded the Central American region in the 1980s were worsened by armed conflicts in Honduras, El Salvador, and Nicaragua. In this context, under the guidance of the Pan American Health Organization (PAHO), the Health Priority Needs Plan for Central America and Panama, then called the Central American Health Initiative, was approved and endorsed in 1984. The driving force was that health would serve as a bridge for peace as common problems were identified and countries solved them together (27). The plan was presented to the countries of the Contadora Group (Colombia, Mexico, Panama, and Venezuela) and other international forums, including the World Health Assembly in 1984, urging international assistance to develop the initiative. In fact, most national and two-thirds of subregional projects were wholly or partly executed in the following years (28). In 1990, inspired by these promising results, the second phase of the Central American Health Initiative was presented with the motto Health and Peace for Development and Democracy in Central America $(29,30)$.

The experience acquired in Central America led PAHO to propose the Caribbean Cooperation in Health in 1984, which sought to foster intercountry cooperation and to strengthen health systems. This initiative gained international recognition as an innovative mechanism for health development, which succeeded in obtaining US\$31 million in external funding in June 1990 (25). An assessment of the initiative in 1992-1994 verified that its priorities and activities appropriately focused on areas critical to improving regional health and that the initiative was beneficial to Caribbean countries. Thus, in 1996, the second phase of the Caribbean Cooperation in Health for the period 1997-2001 was approved (31).

CAN had a similar experience in 1987 with the Andean Cooperation in Health, which aimed to reduce marginalization of the Andean population by identifying key common problems and recommending use of regional resources and expertise. The cooperation seeks to strengthen national and subregional capacity in health through better use of technical resources and autochthonous institutions. Institutionalization of the process implies that, as countries seize the plan, greater participation of institutions is achieved (32).

\section{Institutional reorganization}

The distinctive feature of this phase, conventionally begun in 1990, is the legal and institutional reorganization of subregional blocs. In some cases, this reorganization resulted from new roles assumed by heads of state in integration policies. In other cases, new political and institutional bodies gave greater responsibilities to ministers of health and foreign affairs. Together, they expressed the institutional strengthening of health issues in the political agendas of LAC communities.

The first act in this historic sequence was creation of the Council of Central American Health Ministers in 1991. The new Central American Integration System was then established with the Declaration of Tegucigalpa. According to the Central American Court of Justice, the declaration became the constituent treaty of greater hierarchy in Central American integration, reconfiguring it as a legally organized region (33). ${ }^{5}$

Institutional reorganization in the Amazon region has evolved more slowly. The initial relevant act in the health field occurred in 1987 with creation of the sectoral coordinating body of the Amazon Cooperation Council: the Special Commission of the Amazon Region on Health, responsible for encouraging, coordinating, and supervising implementation of regional health programs undertaken by the treaty (26).
A related process begun 11 years earlier culminated in December 2002 when the permanent secretariat of ACTO was created. This brief historic review shows the prominence of health in the context of international institutions in the Amazon region.

The Andean region has also undergone institutional reform, sealed in 1996 with the Protocol of Trujillo, which substituted the Andean Pact with the Andean Community and created the Andean Integration System. The Hipólito Unanue Agreement was attached to the Andean Integration System, and the name Andean Health Organization was added to the original agreement (24). Furthermore, the Andean Foreign Ministers Council joined the new Andean Integration System, facilitating discussions of health problems within the foreign policy framework of the bloc (34). This new institutional architecture had important implications for the convergence of foreign policies and health policies of member countries and the bloc as a whole. A concrete result of this institutional reconfiguration was the Integrated Social Development Plan, approved in 2004 (35).

The last Latin American subregional bloc established in the 20th century was MERCOSUR, created by the Treaty of Asunción in 1991. Several authors argue that MERCOSUR is essentially an economic and trade bloc and that the lack of social characteristics differentiates it from other regional blocs $(36,37)$. Its initial structure did not include any social areas, much less health. Nevertheless, the dynamics of integration made it necessary to include these fields, which was done in December 1994 with the Protocol of Ouro Preto, which created the Joint Parliamentary Commission and the Economic and Social Advisory Forum within the institutional structure of MERCOSUR. Another relevant measure was adopted in 1995 with creation of the Meeting of Health Ministers of MERCOSUR. In 1996, the Common Market Group en-

\footnotetext{
${ }^{5}$ According to the International Court of Justice in the Advisory Opinion on the Legality of the Use by a State of Nuclear Weapons in Armed Conflict, constituent treaties are multilateral treaties that allow for secondary supranational delegations and create subjects of law endowed with certain autonomy to which the parties entrust the task of realizing common goals.
} 
dorsed the Health Sub-Working Group 11 (SGT-11) as a deliberative technical body with the goal of harmonizing the laws of member states in terms of health goods, services, raw materials, and products as well as adopting criteria for epidemiologic and sanitary surveillance. Therefore, health has become part of the diplomatic context of MERCOSUR, albeit under the aegis of an economic and trade framework.

\section{Regional strengthening}

The final phase began when the Millennium Declaration of the UN triggered a set of global commitments translated into targets related to millennium development goals. These commitments turned into policies within the subregional blocs and increased the demand for health cooperation, given its preponderance in all the goals. As a result, this phase is characterized by the proliferation of international cooperation processes in health with objectives and goals based on global commitments but with strategies and operations that increasingly depended on regional initiatives.

Within CARICOM, the Regional Plan for the Prevention and Control of NonCommunicable Chronic Diseases, approved by heads of state in 2002, has become the core priority of the Third Phase of the Caribbean Cooperation in Health Initiative (38). MERCOSUR intergovernmental health commissions have promoted and approved plans, strategies, policies, and regulations in several areas, such as dengue control in 2004, access to antiretroviral drugs in 2004, reduced mother-to-child transmission of HIV and congenital syphilis in 2004, tobacco control in 2003-2005, and sexual and reproductive health in $2005 .^{6}$

Progress at the political level was noted at ACTO in 2004, with the approval of its strategic plan for 2004-2012 (39). However, slowness and inertia have persisted, as observed in the Amazon Health Plan 2007-2012 announced in 2006, which has produced no results. The Health Agenda of Central America and the Dominican Republic 2009-2018, approved in 2009, contains policy guidelines and priorities for investment in the region and seeks effective harmonization and alignment of external cooperation in terms of regional strategic objectives within the framework of the millennium development goals.

In addition to this range of experiences in health cooperation in the context of regional integration, another bloc of Latin American countries was set up in the new millennium: UNASUR. The concept was to create a space for cultural, social, economic, and political integration among the people, giving priority to social policies (40). The South American Health Council was created at the first meeting of heads of state and government, held in Brazil in December 2008, and the first Constituent Meeting of the South American Health Council took place in April 2009. At these meetings, important decisions were made, such as approval of the health agenda and other recommendations. Over the next 2 years, five working groups, ${ }^{7}$ an equal number of structuring institution networks, and the South American Institute of Health Governance were established. In the words of Buss and Ferreira (41), "this large intergovernmental array called UNASUR Salud is a great example of 'South-South cooperation' and 'health diplomacy' which the South American countries and their Ministries of External Relations and Ministers of Health offer the world."

\section{CONCLUSION}

The development of subregional integration processes shows that all LAC blocs, to a greater or lesser extent, included health in their general objectives and established political and institutional bodies dedicated to this field. Despite drawbacks inherent in integration processes, LAC countries have for four decades practiced a type of health cooperation that fits perfectly with the term that has been considered a novelty: SSC.

One cannot deny the innovative character of this "new" meaning as the his-

\footnotetext{
${ }^{6}$ Regional coordination has been established at broader international forums, such as adoption of common positions on issues like international health regulations and the declaration of South American health ministers on health, innovation, and intellectual property.

7 The topics of the five working groups are: South American network of health surveillance and response, development of universal health systems, universal access to medicine, health promotion and action on the determinants of health, and development and management of human resources for health.
}

toric and multidimensional construction of a concept. This exploratory study strengthens the notion that the conceptual and methodologic foundations of SSC in health were born from the processes of regional integration in LAC and have since been nurtured by them. Many elements of the so-called new paradigm of SSC - such as the exchange of good practices, the building of national and regional capacity by strengthening autochthonous institutions, and the training of local human resourcesdeveloped as regional integration processes evolved.

It is postulated that regional political and economic integration initiatives not only reduce economic and noneconomic transaction barriers but also bring potential benefits to the health sector, hence becoming an important development mechanism for SSC. For example, regional integration agreements can benefit member states by providing economies of scale in the procurement of drugs and vaccines; allowing for seamless health care reforms in individual countries, despite frequent changes in leadership, because of regional commitments that bind them together; facilitating the exchange of good practices because of better understanding and adaptation to local contexts; and providing mechanisms for joint action on cross-border issues, such as floods, droughts, and disease outbreaks. In short, regional integration agreements allow member states to tackle health issues in ways they could not do on their own because of technical and financial limitations.

Many questions remain unanswered. How do these historic actions relate to the present context of World Health Organization policies or the Global Fund? Has cooperation in the health domain been stronger than in other fields? How can the benefits and limitations of southsouth cooperation be objectively evaluated? Furthering this line of research would not only be appropriate but could provide critical input for national and multilateral agencies, or other stakeholders, enabling them to formulate and implement better policies for international health cooperation that are targeted at reducing inequities and promoting the health and the well-being of all people through all means. 


\section{REFERENCES}

1. Morais SSM. How did we get here? The pathways of south-south cooperation. Poverty Focus. 2010;20:3-4.

2. Ayllón, B. Cooperación sur-sur: innovación y transformación en la cooperación internacional. Madrid: Fundación Carolina; 2009. Available from: http://www.fundacioncaro lina.es/es-ES/nombrespropios/Documents/ NPBAyll\%C3\%B3n0912.pdf Accessed 9 October 2012.

3. Santana JP. Um olhar sobre a cooperação sul-sul em saúde. Cien Saude Colet. 2011;16(6):2415-24. Available from: http:// www.scielo.br/scielo.php?script=sci arttext\&pid=S1413-81232011000600037\&lng= en\&nrm=iso\&tlng=pt Accessed 18 August 2011.

4. Almeida C, Campos R, Buss P, Ferreira R, Fonseca L. A concepção brasileira de "cooperação sul-sul estruturante em saúde." Saude Glob Diplomacia Saude. 2010;4(1):25-35.

5. United Nations Development Programme. Buenos Aires Plan of Action. Buenos Aires: UNDP; 1998. Available from: http:// ssc.undp.org/content/dam/ssc/documents/ Key\%20Policy\%20Documents/Buenos\%20 Aires\%20Plan\%20of\%20Action.pdf Accessed 9 October 2012.

6. Lengyel M, Thury V, Malacalzavan B. La eficacia de la ayuda al desarrollo en contextos de fragilidad estatal: Haití y la cooperación latinoamericana. Madrid: Fundación Carolina CeALCI; 2010. (Avances de Investigación 34).

7. Alesina A, Dollar D. Who gives foreign aid to whom and why? J Econ Growth. 2000;2(1):3363.

8. Bird G. The political economy of foreign aid: fatigue or regeneration? Zagreb Int Rev Econ Bus. 1999;2(2):1-24.

9. Collier P, Guillaumont P, Guillaumont S, Gunning J. Redesigning conditionality. World Dev. 1997;25(9):1399-407.

10. Kharas $\mathrm{H}$. The new reality of aid. Washington, D.C.: Brookings Institution; 2007. Available from: http:/ / www.brookings.edu/global/ aspen/2007kharas.pdf Accessed 26 July 2011.

11. Maizels A, Nissanke M. Motivations for aid to developing countries. World Dev. 1984;12(9):879-900.

12. Stone, RW. Buying influence: the political economy of international aid. 2006 International Studies Association Annual Convention, 22-26 March. San Diego: International Studies Association; 2006.

13. Morguenthau H. A political theory of foreign aid. Am Pol Sci Rev. 1962;56(2):301-9.

14. Sogge, D. Give and take: what's the matter with foreign aid? New York: St. Martin's Press; 2002.

15. Sanahuja J. Entre los objetivos de desarrollo del milenio y la cooperación sur-sur: actores y políticas de la ayuda al desarrollo en América Latina y el Caribe. Pensamiento Iberoamericano. 2011;8:195-222.

16. Ayllón B, Leite I. La cooperación sur-sur de Brasil: ¿instrumento de política exterior y/o manifestación de solidaridad internacional? Mural Int. 2010;1:20-32. Available from:
http://www.ppgri.uerj.br/pdf/Mural_inter nacional.pdf Accessed 31 March 2011.

17. Task Team on South-South Co-operation. Boosting south-south cooperation in the context of aid effectiveness: telling the story of partners involved in more than 110 cases of south-south and triangular cooperation. Paris: Organisation for Economic Co-operation and Development; 2010. Available from: http:// www.oecd.org/dataoecd/14/63/46080462. pdf Accessed 22 March 2011.

18. Reality of Aid Management Committee. Special report on south-south cooperation 2010. Quezon City, Philippines: IBON Books; 2010. Available from: http://reliefweb.int/sites/ reliefweb.int/files/resources/E7CA78D6 C6C901D0C125775400224AA6-ROA\%20SS DC\% 20Special\% 20Report\% 28English \%29\%5B1\%5D.pdf Accessed 12 April 2011.

19. Hirst M. Aspectos conceituais e práticos da atuação do Brasil em cooperação sul-sul: os casos de Haiti, Bolívia e Guiné Bissau. Texto para Discussão 1687. Brasilia: Instituto de Pesquisa Econômica Aplicada; 2012.

20. United Nations. Ministerial Declaration of the 33rd Annual Meeting of the Ministers of Foreign Affairs of the Member States of the Group of 77 and China. New York: The Group of 77; 2009. Available from: http://www.g77. org/doc/Declaration2009.htm Accessed 30 March 2011

21. Rowlands D. Emerging donors in international development assistance: a synthesis report. Ottawa: International Development Research Centre Partnership and Business Development Division; 2008. Available from: http:/ / web.idrc.ca/uploads/userS/12278143331Synthesis_Final.pdf Accessed 12 April 2011.

22. Arroyo J. Diagnóstico base para la formulación de la estrategia de cooperación andina en salud de OPS/OMS. Lima: Organización Panamericana de la Salud/Organización Mundial de la Salud; 2008. Available from: http: / / www.bvsde.paho.org/texcom/ sct/045608.pdf Accessed 3 March 2010. (Documento de trabajo).

23. La Comunidad Andina. Decisión 563. Codificación del Acuerdo de Integración Subregional Andino (Acuerdo de Cartagena). Cartagena: CAN; 2003. (Gaceta Oficial de la Comunidad Andina 940). Available from: http://www.comunidadandina.org/norma tiva/dec/d563.htm Accessed 30 March 2010.

24. Organismo Andino de Salud, Convenio Hipólito Unanue. Instrumentos jurídicos. Lima: ORAS-CONHU; 2007.

25. Alleyne G, Sealey K. Cooperación Caribeña en materia de salud. Integr Latinoam. 1991; 16(164):13-20

26. Tratado de Cooperación Amazônica, Secretaría Pro Tempore. Base jurídica del Tratado de Cooperación Amazónica: antecedentes constitutivos de la Organización del Tratado de Cooperación Amazónica (OTCA). La Paz: OTCA; 2002.

27. Organización Panamericana de la Salud Plan básico sobre necesidades prioritarias de salud de Centroamérica y Panamá. Washington, D.C.: OPS; 1984. Available from: http:/ / webcache.googleusercontent.com/ search?q=cache:http:/ / hist.library.paho.org/ Spanish/GOV/CD/25953.pdf Accessed 9 October 2012.

28. Cruz-Peñate ME. Salud e historia en Centroamérica: análisis de las reuniones del sector salud de Centroamérica y República Dominicana 1985-2000. Managua: Organización Panamericana de la Salud; 2001.

29. Declaración de Montelimar. VII Cumbre de Presidentes Centroamericanos, Montelimar, República de Nicaragua, 3 April 1990. Montelimar, Nicaragua: Secretariat for Central American Economic Integration; 1990. Available from: http://www.sieca.int/site/ Cache/17990000001145/17990000001145.pdf Accessed 9 October 2012.

30. Declaración de Belice: salud y paz hacia el desarrollo y la democracia en Centroamérica. Rev Centroamericana Administración Pública. 1993;25(9):155-8. Available from: http://unpan1.un.org/intradoc/groups/ public/documents/icap/unpan038317.pdf Accessed 9 October 2012.

31. Caribbean Cooperation in Health Secretariat. Caribbean Cooperation in Health Phase II: a new vision for Caribbean health. Bridgetown, Barbados: Caribbean Community; 1999

32. Ochoa L, Gauldfeldt F. Cooperación Andina en salud (CAS). Integr Latinoam. 1991; 16(164):7-12.

33. Gallard J. La salud en los procesos de globalización e integración en Centroamérica. Washington, D.C.: Organización Panamericana de la Salud; 1997. (Serie de Informes Técnicos 59).

34. Pareja C. La dimensión social de la integración Andina. Rev Integr Andina. 2009; June 4:147-59.

35. Consejo Andino de Ministros de Relaciones Exteriores. Decisión 601: Plan Integrado de Desarrollo Social. New York: Consejo Andino de Ministros de Relaciones Exteriores; 2004. Available from: www.comunidadandina. org/normativa/dec/DEC601.pdf Accessed 30 March 2010

36. Dal Prá KR, Mendes JMR, Mioto RCT. O desafio da integração social no MERCOSUL: uma discussão sobre a cidadania e o direito à saúde. Cad Saude Publica. 2007;23(Suppl.2):S164-73.

37. Tobar S. Integración en salud desde MERCOSUR. In: Organismo Andino de Salud-Convenio Hipólito Unanue. La salud en los procesos de integración: memorias. Lima: ORAS-CONHU; 2009. Pp. 35-7.

38. Caribbean Community Secretariat. Health $=$ wealth: synthesis of the report of the Caribbean Commission on Health and Development (CCHD). Georgetown, Guyana: Caribbean Community Secretariat; 2007.

39. Organización del Tratado de Cooperación Amazónica. Cumbre de Manaos. Ministros de los países amazónicos fortalecen la OTCA y refuerzan cooperación regional. Bol OTCA. 2004;1(2):4-5.

40. Unión de Naciones Suramericanas. Tratado Constitutivo de la Unión de Naciones 
Suramericanas. Quito: Comunidad Andina, Secretaría General; 2008. Available from: http:// www.comunidadandina.org/un asur/tratado_constitutivo.htm Accessed 30 June 2010.
41. Buss P, Ferreira R. Health diplomacy and south-south cooperation: the experiences of UNASUR Salud and CPLP's Strategic Plan for Cooperation in Health. Rev Electron Comun Inf Inov Saude. 2010;4(1):99-110.
Manuscript received on 29 November 2011. Revised version accepted for publication on 30 July 2012.

RESUMEN Este artículo analiza si la cooperación sur-sur constituye legítimamente una práctica reciente o es solo una versión mejorada de los procesos anteriores de integración regional en América Latina y el Caribe. Los autores analizaron y sistematizaron el

Integración regional y cooperación sur-sur en materia de salud en América Latina y el Caribe desarrollo histórico de los procesos de integración subregional en América Latina y el Caribe y se centraron en la cooperación en materia de salud en los siguientes contextos: el Sistema de Integración Centroamericana, la Comunidad Andina de Naciones, la Comunidad del Caribe, la Organización del Tratado de Cooperación Amazónica, el Mercado Común del Sur y la Unión de Naciones Suramericanas. El estudio concluye que las bases conceptuales y metodológicas de la cooperación sur-sur en materia de salud nacieron y se nutrieron de los procesos de integración regional en América Latina y el Caribe. Este artículo postula que las iniciativas regionales de integración política y económica aportan beneficios potenciales al sector de la salud y actúan como un mecanismo importante para desarrollar la cooperación sur-sur en este dominio. El estudio recomienda fomentar este tipo de investigaciones con objeto de proporcionar información que permitirá a los organismos nacionales y multilaterales, o a otros interesados directos, formular e implantar mejoras en las políticas de cooperación internacional en materia de salud que tengan como meta la reducción de las desigualdades y la promoción de la salud y del bienestar de todas las personas.

Palabras clave Cooperación internacional; cooperación técnica; cooperación horizontal; América Latina. 